\title{
SUBCUTANEOUS CONNECTIVE TISSUE REACTIONS TO NEW CALCIUM SILICATE CEMENTS: AN ANIMAL STUDY
}

\author{
Seçil ÇALIŞKAN ${ }^{1 *}$, Nuray TÜLOĞLU1 ${ }^{1}$, Barış KARABULUT ${ }^{2}$, Ceren CANBEY ${ }^{3}$, Şule BAYRAK ${ }^{1}$ \\ ${ }^{1}$ Department of Pediatric Dentistry, Faculty of Dentistry, Eskisehir Osmangazi University, 26480, Eskisehir, Turkey \\ ${ }^{2}$ Department of Pedodontics, Faculty of Dentistry, Health Sciences University, 34668, Istanbul, Turkey \\ ${ }^{3}$ Department of Surgical Pathology, Health Sciences University, Bagcilar Research and Education Hospital, 34200, Istanbul, Turkey
}

\begin{abstract}
The aim of this study was to determine the subcutaneous connective tissue reactions to Medcem MTA and Medcem Pure Portland Cement. Medcem MTA, Medcem Pure Portland Cement and ProRoot MTA were placed in polyethylene tubes and implanted into the dorsal connective tissue of Sprague Dawley rats. The presence of inflammation, edema, necrosis, dystrophic calcification, and thickness of fibrous capsule formation was recorded by histological examination 7, 30, and 60 days after the implantation procedure. Inflammation scores were defined as follows: $0=$ no or few inflammatory cells, no reaction, $1=<25$ cells, mild reaction; $2=25$ to 125 cells, moderate reaction; and $3=\geq 125$ cells, severe reaction. Fibrous capsule thickness, necrosis, and formation of calcification were recorded. The Kruskal-Wallis test and repeated measures analysis of variance were used for statistically analyses $(\mathrm{P}<0.05)$. No significant differences in edema, necrosis and fibrous capsule formation were observed between the groups on any of the three euthanasia days. All experimental groups exhibited significantly more inflammation than the control group. On Day 30 and 60, all experimental groups exhibited significantly more dystrophic calcification than the control group. Medcem MTA and Medcem Pure Portland Cement had similar biocompatibility to ProRoot MTA. Medcem MTA and Medcem Pure Portland Cement with the presence of dystrophic calcification in connective tissue have the potential to be clinic use as calcium silicate materials.
\end{abstract}

Keywords: Biocompatible materials, Dental material, Mineral trioxide aggregate

*Corresponding author: Department of Pediatric Dentistry, Faculty of Dentistry, Eskisehir Osmangazi University, 26480, Eskisehir, Turkey

E mail: sclctn@hotmail.com (S. ÇALIŞKAN)

Seçil ÇALIŞKAN (iD) https://orcid.org/0000-0002-8099-584X

Nuray TÜLOĞLU (D) https://orcid.org/0000-0001-6410-9126

Barıș KARABULUT (iD) https://orcid.org/0000-0001-5556-6237

Ceren CANBEY (iD) https://orcid.org/0000-0003-0564-4158

Şule BAYRAK (iD) https://orcid.org/0000-0001-7023-2358

Received: March 02, 2021

Accepted: March 22, 2021

Published: September 01, 2021

Cite as: Çalıșkan S, Tüloğlu N, Karabulut B, Canbey C, Bayrak Ş. 2021. Subcutaneous connective tissue reactions to new calcium silicate cements: An animal study. BSJ Health Sci, 4(3): 213-220.

\section{Introduction}

Biocompatibility is defined as the physical, chemical, and biological compatibility of a material implanted into living tissue and its adaptation to the body's mechanical behavior. Materials used in endodontics are frequently placed in close contact with the periodontium and should have no detrimental effects on it (Bósio et al., 2014). Tissue reactions to endodontic treatment may be influenced by various factors related to the chemical nature, content, substance release, and differences in the contents of the materials used (Kaplan et al., 2003; Marques et al., 2013). Almost all endodontic materials contain trace elements such as aluminum, bismuth oxide, and zirconium oxide. These trace elements may cause various reactions when in contact with tissues, depending on the type of substance and the amount released (Hungaro Duarte et al., 2009). It is therefore necessary to understand the cellular events triggered by interactions between biomaterials and tissues.

Calcium silicate-based materials have recently gained popularity in endodontic treatments. These materials have excellent properties, as they are biocompatible, antibacterial, noncytotoxic, nonmutagenic, nongenotoxic, and noncarcinogenic (Torabinejad et al., 1995; Saidon et al., 2003; Zmener et al., 2012). Various forms of calcium silicate-based materials have produced superior outcomes (Shayegan et al., 2012; Dawood et al., 2017; Parirokh et al., 2018). Mineral trioxide aggregate (MTA) was the first of this type of materials to be developed and patented in 1995. Because of its biocompatibility and bioactivity, many manufacturers subsequently developed MTA-like products with different compositions and manufacturing processes (Parirokh and Torabinejad, 2010). These materials are widely used in endodontic treatments.

Medcem Pure Portland Cement and Medcem MTA are recently developed calcium silicate-based materials. The aim of this study was to determine the sub cutaneous connective tissue reactions to these new materials. The null hypothesis was that there would be no difference in terms of biocompatibility between Medcem MTA, Medcem Pure Portland Cement, and ProRoot White MTA. 


\section{Material and Methods}

\subsection{Animals and Sample Grouping}

Twenty-four male Sprague Dawley rats weighing 250$300 \mathrm{~g}$ were used in the study. For preliminary study, one rat was used on each experimental day (total three rats for 7.30 and 60 days). During the study period, the animals were kept in cages in groups of five under standard care conditions with no feed and water supply restrictions.

Table 1. Experimental materials used in the study
ProRoot White MTA, Medcem Pure Portland Cement, and Medcem MTA mixed according to the manufacturers' instructions were placed in polyethylene tubules (internal diameter: $1.3 \mathrm{~mm}$, external diameter: $1.6 \mathrm{~mm}$, length: $5 \mathrm{~mm}$ ) sterilized with ethylene oxide gas, as specified by ISO (International Organization for Standardization), using a sterile Lentulo. Twenty-one empty polyethylene tubes were used in the control group. The materials used in the study were listed in Table 1.

\begin{tabular}{|c|c|c|c|c|}
\hline Group & Brand Name & Material & Composition & Manufacturer \\
\hline 1 & $\begin{array}{l}\text { ProRoot White MTA } \\
\text { Lot No: } 0000154618\end{array}$ & $\begin{array}{l}\text { White mineral } \\
\text { trioxide } \\
\text { aggregate }\end{array}$ & $\begin{array}{c}\text { Portland cement (tricalcium } \\
\text { silicate, } \\
\text { tricalcium aluminate, } \\
\text { dicalcium silicate, } \\
\text { tetracalcium } \\
\text { aluminoferrite), bismuth } \\
\text { oxide }\end{array}$ & $\begin{array}{c}\text { Dentsply, Tulsa } \\
\text { Dental, Johnson City, TN, } \\
\text { USA }\end{array}$ \\
\hline 2 & $\begin{array}{c}\text { Medcem Pure Portland } \\
\text { Cement } \\
\text { Lot No: MTZ181020 }\end{array}$ & $\begin{array}{l}\text { Portland } \\
\text { cement }\end{array}$ & $\begin{array}{c}\text { Portland cement (tricalcium } \\
\text { silicate, } \\
\text { tricalcium aluminate, } \\
\text { dicalcium silicate, } \\
\text { tetracalcium } \\
\text { aluminoferrite) }\end{array}$ & $\begin{array}{l}\text { Medcem, Weinfelden, } \\
\text { Switzerland }\end{array}$ \\
\hline 3 & $\begin{array}{c}\text { Medcem MTA } \\
\text { Lot No: RX181020 }\end{array}$ & $\begin{array}{l}\text { Mineral } \\
\text { trioxide } \\
\text { aggregate }\end{array}$ & $\begin{array}{l}\text { Portland cement (tricalcium } \\
\text { silicate, } \\
\text { tricalcium aluminate, } \\
\text { dicalcium silicate, } \\
\text { tetracalcium } \\
\text { aluminoferrite), zirconium } \\
\text { oxide }\end{array}$ & $\begin{array}{l}\text { Medcem, Weinfelden, } \\
\text { Switzerland }\end{array}$ \\
\hline
\end{tabular}

\subsection{Surgical Procedures}

The rats were anesthetized in an ether jar and then received $70-\mathrm{mg} / \mathrm{kg}$ ketamine and $10-\mathrm{mg} / \mathrm{kg}$ xylazine intraperitoneally. The operation area (back) of each rat was shaved with a razor blade, disinfected with povidone-iodine Betadine skin disinfectant, and covered with sterile drapes. To induce local hemostasis, $0.5 \mathrm{cc}$, 0.006-mg/ml 4\% articaine containing epinephrine (Ultracaine D-S-Aventis Forte, Istanbul, Turkey) was administered.

Incision lines were marked on the dorsal, anterior, and posterior extremities of the animals, two in the anterior and two in the posterior region. Care was taken to keep a distance of at least $2 \mathrm{~cm}$ between the placed materials to prevent them from being affected from each other. Incisions approximately $1 \mathrm{~cm}$ long were made with a sterile scalpel. Canals were entered through the incision site with a sterile periosteal elevator, and ducts were opened under the skin by blunt dissection approximately $2 \mathrm{~cm}$ deep. Subsequently, polyethylene tubes filled with the experimental material of each group and empty polyethylene tubes for the control group were placed in the prepared subcutaneous canals. The incision sites were then sutured primarily using $3 / 0$ silk. Antibacterial spray was applied on the sutures.

\subsection{Histological Procedures}

After surgery, seven animals from each group (21 animals) were euthanized with high doses of thiopentalsodium (Pental, İ.E. Ulagay Med. Ind., Istanbul, Turkey) administered intraperitoneally under ether anesthesia on days 7,30 , and 60 . The test tubes were then removed together with the surrounding tissues and placed in bottles containing $10 \%$ neutral formalin. Paraffin blocks were prepared from samples fixed in $10 \%$ formalin for two days. From the tissues embedded in the paraffin blocks, 4- $\mu$ m serial sections parallel to the long axis of the tube were cut with a microtome (Leica SM 2000R, Leica Instruments, Wetzlar, Germany) and stained with hematoxylin and eosin (H\&E).

The tissue samples were histologically examined under an optical microscope (Nikon Eclipse E600, Nikon Corp., Tokyo, Japan) at 40x, 100x, 200x, and 400x magnification (Figures 1, 2, and 3). All slides were examined and rated by a pathologist blinded to all procedures. The histological evaluation criteria are shown in Table 2 (Maeda et al., 1999). 

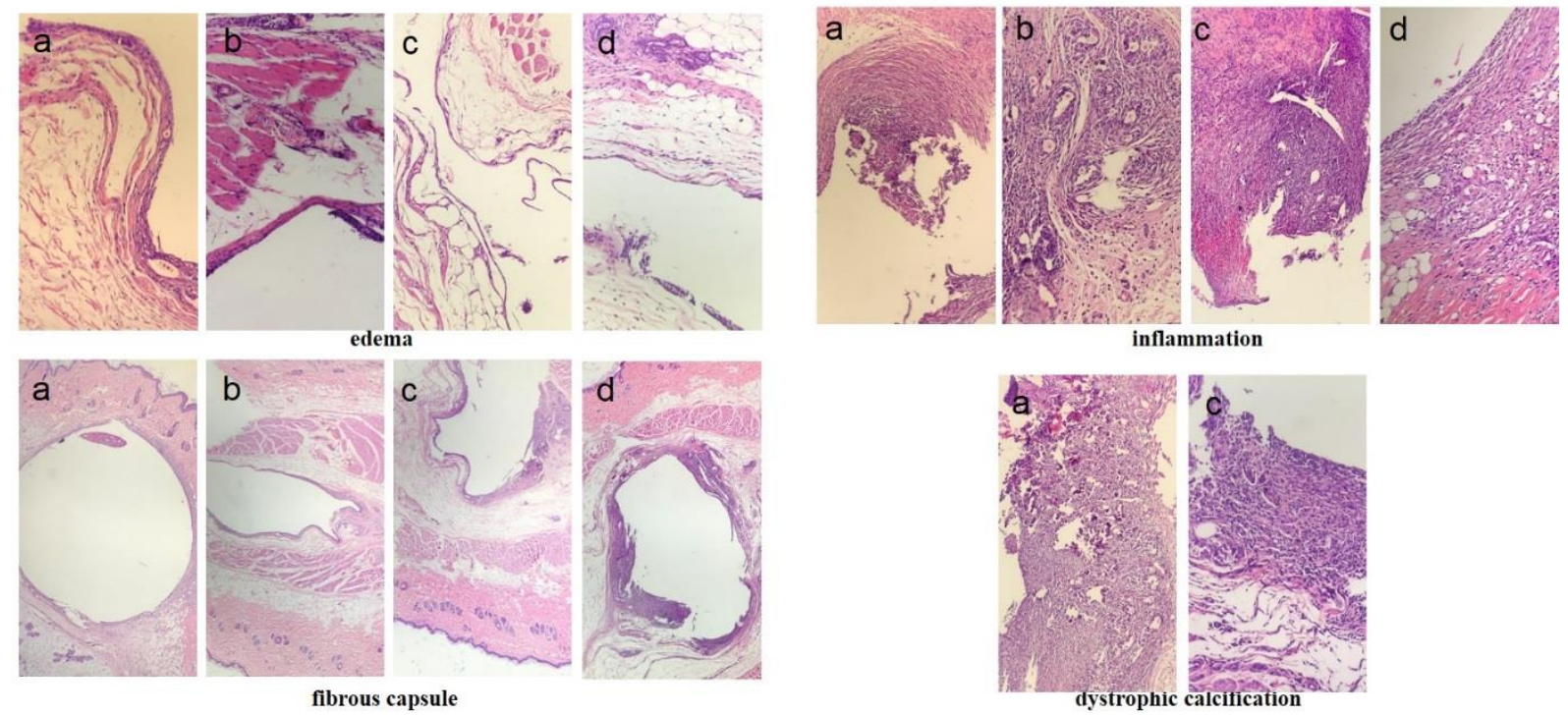

Figure 1. Photomicrograph of H\&E staining showing subcutaneous tissue of the (A) control, (B) ProRoot White MTA, (C) Medcem Pure Portland Cement, and (D) Medcem MTA groups after seven days. Edematous loose connective tissue was observed, especially in areas around the fibrous capsule (H\&E 100× and 200×). Intense inflammation was detected around the fibrous capsule (H\&E 100x and 400×). Thin fibrous capsule formation was observed (H\&E 40×). Dystrophic calcification was observed around and inside the fibrous capsule (H\&E 100×).
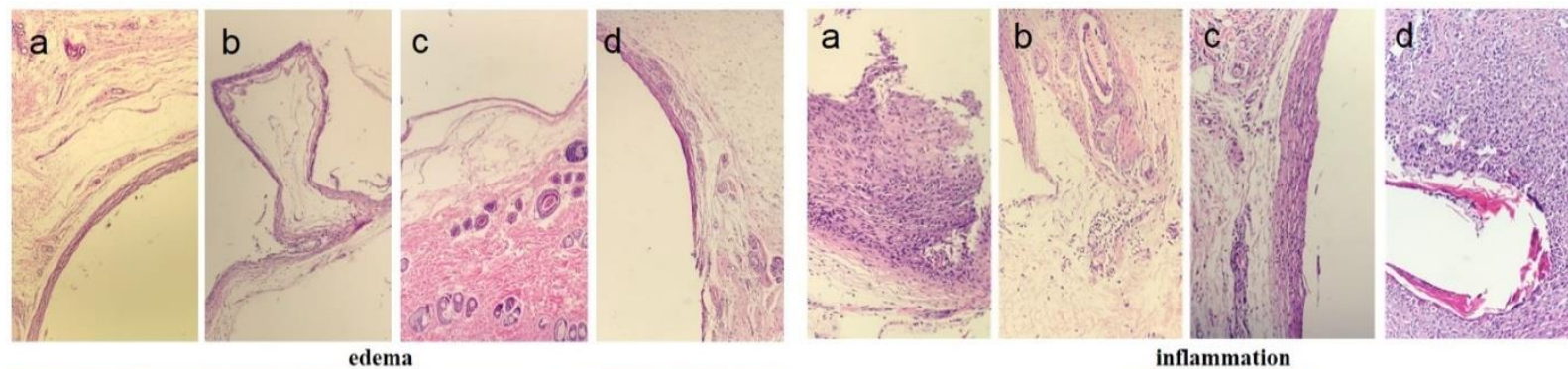

inflammation

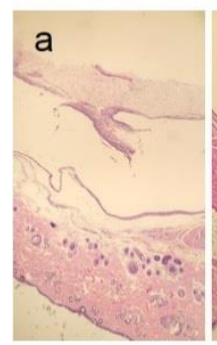

b

lem

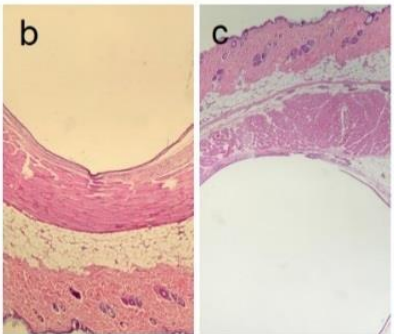

fibrous capsule

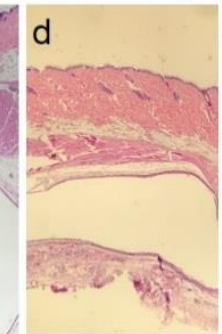

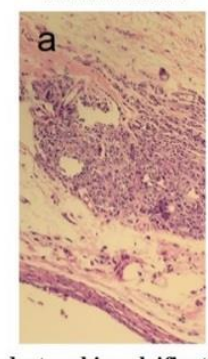

dystrophic calcification

Figure 2. Photomicrograph of H\&E staining showing subcutaneous tissue of the (A) control, (B) ProRoot White MTA, (C) Medcem Pure Portland Cement, and (D) Medcem MTA groups after 30 days. Edematous loose connective tissue was observed, especially in areas around the fibrous capsule (H\&E 100× and 200×). Intense inflammation was detected around the fibrous capsule (H\&E 100× and 400×). Thin fibrous capsule formation was observed (H\&E 40×). Dystrophic calcification was observed around and inside the fibrous capsule (H\&E 100×). 

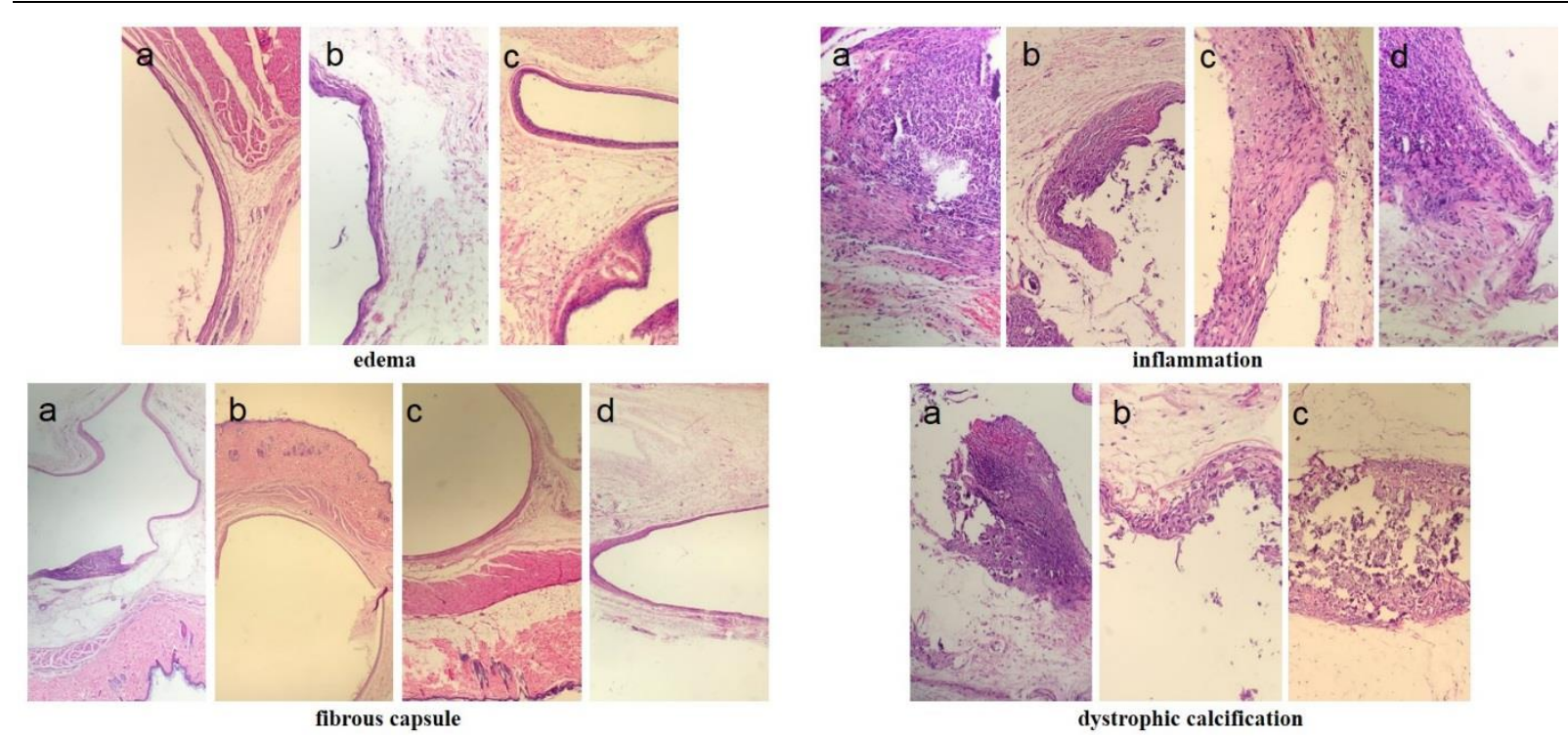

Figure 3. Photomicrograph of H\&E staining showing subcutaneous tissue of the (A) control, (B) ProRoot White MTA, (C) Medcem Pure Portland Cement, and (D) Medcem MTA groups after 60 days. Edematous loose connective tissue was observed, especially in areas around the fibrous capsule (H\&E 100x and 200x). Intense inflammation was detected around the fibrous capsule (H\&E 100x and 400×). Thin fibrous capsule formation was observed (H\&E 40×). Dystrophic calcification was observed around and inside the fibrous capsule (H\&E 100×).

Table 2. Histological evaluation scores

Dystrophic calcification
0: Absent
1: Present
Necrosis
0: Absent
1: Present
Edema
0: Absent
1: Present
Inflammation
0: No or few inflammatory cells and no reaction
1: Fewer than 25 inflammatory cells and mild
reaction
2: Between 25 and 125 inflammatory cells and
moderate reaction
3: 126 or more inflammatory cells and severe
reaction
Fibrous capsule formation
0: Absent
1: Present

\subsection{Statistical Analysis}

Statistical analysis was performed using IBM SPSS Statistics version 22 (IBM Corp, Armonk, NY, USA). The Kruskal-Wallis test and repeated measures analysis of variance were used. Statistical significance was defined as $\mathrm{P}<0.05$.

\section{Results}

The animals tolerated the surgical procedures well. No apparent adverse events occurred during the study period of 60 days. No significant differences in edema were observed between the groups on any of the three euthanasia days. On Day 7, edema was detected in all groups. However, on Day 30 and 60, no signs of edema were observed in the control and Medcem MTA groups (Table 3). Moreover, on Day 30 and 60, edema decreased compared to Day 7 in all groups (Table 3). The decrease was not statistically significant in the Medcem Pure Portland Cement group, but it was significant in the ProRoot White MTA group ( $\mathrm{P}=0.026)$.

Necrosis was not detected in any group at any point during the experiment (Table 4). In the control group, inflammatory cell response did not vary significantly over time. All experimental groups exhibited significantly more inflammation than the control group. On Day 7, significantly more inflammation was observed in the ProRoot White MTA and Medcem Pure Portland Cement groups than in the control group $(\mathrm{P}=0.006)$. There were no significant differences between the four groups on Day 30. On Day 60, significantly more inflammation was observed in the Medcem Pure Portland Cement than in the other groups $(\mathrm{P}=0.029)$. The ProRoot White MTA and Medcem Pure Portland Cement groups exhibited mostly moderate inflammation on Day 7 , which decreased significantly over time $(\mathrm{P}=0.001$ and $\mathrm{P}=$ 0.003, respectively; Table 5). In the Medcem MTA group, inflammatory cell response varied significantly over time $(P=0.001)$, with the highest response observed on Day 7 and no inflammation observed on Day 60.

No significant differences in fibrous capsule formation were found between the four groups at any point during the study period. Fibrous capsule formation was observed during the entire experimental period in the control group (Table 6).

No dystrophic calcification was detected in the control group at any point (Table 7). On Day 7, the control group 
differed significantly only from the ProRoot White MTA group, which exhibited the most dystrophic calcification $(P=0.036)$. On Day 30 and 60, all experimental groups exhibited significantly more dystrophic calcification than the control group (all $\mathrm{P}<0.001$ ), whereas the differences between them were not statistically significant. In all experimental groups, dystrophic calcification increased on Day 30 and 60 compared to Day 7 (Table 7); however, the increase was not statistically significant in any group.

Table 3. Distribution of edema by group

\begin{tabular}{|c|c|c|c|c|c|c|}
\hline \multirow[b]{3}{*}{ Group } & \multicolumn{6}{|c|}{ Edema } \\
\hline & \multicolumn{2}{|c|}{ Day 7} & \multicolumn{2}{|c|}{ Day 30} & \multicolumn{2}{|c|}{ Day 60} \\
\hline & Present & Absent & Present & Absent & Present & Absent \\
\hline ProRoot White MTA & 7 & 0 & 3 & 4 & 3 & 4 \\
\hline Medcem Pure Portland Cement & 6 & 1 & 3 & 4 & 2 & 5 \\
\hline Medcem MTA & 7 & 0 & 0 & 7 & 0 & 7 \\
\hline Control & 5 & 2 & 0 & 7 & 0 & 7 \\
\hline
\end{tabular}

Table 4. Distribution of necrosis by group

\begin{tabular}{lcccccc}
\hline & \multicolumn{3}{c}{ Necrosis } \\
\cline { 2 - 7 } Group & \multicolumn{2}{c}{ Day 7 } & \multicolumn{2}{c}{ Day 30 } & \multicolumn{2}{c}{ Day 60 } \\
\cline { 2 - 8 } & Present & Absent & Present & Absent & Present & Absent \\
\hline ProRoot White MTA & 0 & 7 & 0 & 7 & 0 & 7 \\
Medcem Pure Portland Cement & 0 & 7 & 0 & 7 & 0 & 7 \\
Medcem MTA & 0 & 7 & 0 & 7 & 0 & 7 \\
Control & 0 & 7 & 0 & 7 & 0 & 7 \\
\hline
\end{tabular}

Table 5. Distribution of inflammation scores by group

\begin{tabular}{|c|c|c|c|c|c|c|c|c|c|c|c|c|}
\hline \multirow[b]{3}{*}{ Group } & \multicolumn{12}{|c|}{ Inflammation } \\
\hline & \multicolumn{4}{|c|}{ Day 7} & \multicolumn{4}{|c|}{ Day 30} & \multicolumn{4}{|c|}{ Day 60} \\
\hline & 0 & 1 & 2 & 3 & 0 & 1 & 2 & 3 & 0 & 1 & 2 & 3 \\
\hline ProRoot White MTA & 0 & 1 & 5 & 1 & 2 & 5 & 0 & 0 & 5 & 2 & 0 & 0 \\
\hline Medcem Pure Portland Cement & 0 & 1 & 5 & 1 & 3 & 4 & 0 & 0 & 3 & 4 & 0 & 0 \\
\hline Medcem MTA & 0 & 5 & 2 & 0 & 4 & 3 & 0 & 0 & 7 & 0 & 0 & 0 \\
\hline Control & 2 & 4 & 1 & 0 & 5 & 2 & 0 & 0 & 7 & 0 & 0 & 0 \\
\hline
\end{tabular}

Table 6. Distribution of fibrous capsule formation by group

\begin{tabular}{lcccccc}
\hline & \multicolumn{4}{c}{ Fibrous Capsule Formation } \\
\cline { 2 - 7 } Group & \multicolumn{2}{c}{ Day 7 } & \multicolumn{3}{c}{ Day 30 } & \multicolumn{2}{c}{ Day 60 } \\
\cline { 2 - 7 } & Present & Absent & Present & Absent & Present & Absent \\
\hline ProRoot White MTA & 4 & 3 & 0 & 7 & 0 & 7 \\
Medcem Pure Portland Cement & 4 & 3 & 0 & 7 & 0 & 7 \\
Medcem MTA & 6 & 1 & 7 & 0 & 6 & 1 \\
Control & 7 & 0 & 7 & 0 & 7 & 0 \\
\hline
\end{tabular}

Table 7. Distribution of dystrophic calcification by group

\begin{tabular}{lcccccc}
\hline & \multicolumn{4}{c}{ Dystrophic Calcification } \\
\cline { 2 - 7 } Group & \multicolumn{2}{c}{ Day 7} & \multicolumn{2}{c}{ Day 30 } & \multicolumn{2}{c}{ Day 60 } \\
\cline { 2 - 7 } & Present & Absent & Present & Absent & Present & Absent \\
\hline ProRoot White MTA & 5 & 2 & 7 & 0 & 7 & 0 \\
Medcem Pure Portland Cement & 2 & 5 & 5 & 2 & 5 & 2 \\
Medcem MTA & 4 & 3 & 7 & 0 & 7 & 0 \\
Control & 0 & 7 & 0 & 7 & 0 & 7 \\
\hline
\end{tabular}

\section{Discussion}

The evaluation of the biocompatibility of newly developed materials is vital in dentistry. Materials should be proven to have no adverse effects on contact with tissues before they are marketed (Cintra et al., 2013; Abou ElReash et al., 2019). The aim of this study was to 
determine the subcutaneous connective tissue reactions of calcium silicate based materials. Many methods are used to evaluate the biocompatibility of endodontic materials (Torneck, 1966; Olsson et al., 1981; Roberts et al., 2008). Implantation into rats' subcutaneous tissues, which was introduced in 1966 and approved in 1981 (Torneck, 1966; Olsson et al., 1981), is one of the most appropriate methods, as it requires the lowest number of variables and can provide exact and detailed information on material-tissue interactions on the cellular level (Olsson et al., 1981).

MTA was the first calcium silicate cement used in dentistry (Jefferies, 2014). Today, many studies use ProRoot White MTA as a standard for comparisons with newly developed calcium silicate-based materials (Camilleri and Pitt Ford, 2006; Bodrumlu, 2008; Junior et al., 2019). ProRoot White MTA stimulates dentin repair without triggering an inflammatory tissue response in the pulp (Junior et al., 2019). Despite its superior biological properties, however, it has certain disadvantages, such as difficult application, long cure time, and low compression resistance compared to dentin. These disadvantages have prompted the development of different MTA formulas. Portland cement is the main component of MTA (Vilimek et al., 2018). Recently, considerable attention has been drawn to the evolution of Portland cement as an alternative to MTA (Sakai et al., 2009; Oliveira et al., 2013; Vilimek et al., 2018). It contains low aluminum and ferric oxide and no heavy metals (such as arsenic, cadmium, and lead), and it has good chemical and physical properties (Islam et al., 2006; Steffen and Van Waes, 2009). It also seems to be a good alternative due to its considerably lower cost (Petrou et al., 2014). MTA and Portland cement have similar properties (compressive strength, dimensional change, setting time, $\mathrm{pH}$ ). The only significant difference is the lower radiopacity of Portland cement. Medcem Pure Portland Cement is a new product that contains no additional ingredients and is characterized by color stability and neutrality. Its X-ray opacity is slightly higher than that of dentine. The recently developed Medcem MTA is a second-generation MTA containing pure Portland cement and zirconium oxide instead of bismuth oxide as a radiopacifier, as the latter is considered responsible for discoloration.

To the best of the authors' knowledge, there is no study that has evaluated the biocompatibility of Medcem Pure Portland Cement and Medcem MTA. As stated in our null hypothesis, there was no significant difference between Medcem MTA, Medcem Pure Portland Cement, and ProRoot White MTA. The results showed no significant differences in terms of calcification, edema, fibrous capsule formation, and necrosis. Therefore, with the exception of inflammatory response, the null hypothesis was accepted.

Few or no reactions were observed in subcutaneous tissue in the control group on days 7 and 30. These reactions were possibly caused by trauma from the surgical procedure and reaction to a foreign body. Normal repair tissues were formed at 60 days. These results are consistent with previous findings (GomesFilho et al., 2009; Cintra et al., 2013; Abou ElReash et al., 2019; Skallevold et al., 2019).

Edema after implantation of tubes into the rats' subcutaneous tissue, which was more common in all groups depending on the surgical procedure, gradually decreased throughout the experimental period (Zhang and Peng, 2015). No edema was observed in the Medcem MTA group during the entire period, which indicated that the material is well tolerated by soft tissue. It has been reported that subcutaneous implantation of MTA initially leads to coagulation necrosis, but reactions mostly regress over time (Moretton et al., 2000). In this study, no necrosis was observed at any point.

Acute inflammatory reaction after surgery is the result of trauma caused by the placement of tubes (Zhang and Peng, 2015). In this study, ProRoot White MTA and Medcem Pure Portland Cement triggered mild to severe inflammatory reactions at seven days. This is partially consistent with the findings of two previous studies on ProRoot White MTA (Lotfi et al., 2009; Saghiri et al., 2012).

The experimental materials used in this study mainly contained calcium silicate, but they also contained different radiopaficiers (bismuth oxide and zirconium oxide). Sabari et al. evaluated inflammatory reactions caused by adding bismuth oxide and zirconium oxide to Portland cement as radiopaficiers and reported tissue responses similar to those induced by ProRoot MTA at 7, 30, and 60 days (Sabari et al., 2019). These findings are consistent with our observations on Day 7 and 30 but inconsistent with those on Day 60. This may be due to the fact that, unlike our study, Sabari et al. (Sabari et al., 2019) did not use commercial products. In another study using another commercial product containing zirconium oxide (iRoot SP), the inflammatory response was comparable to that observed in the control group (Zhang and Peng, 2015). Moreover, ProRoot White MTA and iRoot SP had similar effects at 30 and 60 days. These findings are in line with our study. At 60 days, we observed significantly more inflammation in the Medcem Pure Portland Cement group than in the other groups. The higher alkalinity and heavy metal content of this material may have played a role in the observed difference (Karanth et al., 2013).

MTA implantation into rats' subcutaneous tissue promotes the formation of calcite crystals and a layer of mineralized tissue (Bósio et al., 2014). Sarkar et al. found that tricalcium silicate was dissolved in synthetic tissue fluid, releasing calcium, thus leading to the precipitation of hydroxyapatite (Sarkar et al., 2005). Regions of dystrophic mineralization are considered critical for the differentiation of secondary odontoblasts and subsequent reparative dentine formation (Hinata et al., 2017). Our observation of focal areas of calcification in the capsule surrounding the implant with all test 
materials is consistent with previous studies (Holland et al., 2001; Cintra et al., 2013; Karanth et al., 2013).

Torneck et al. (1966) suggested that the absence of inflammation and necrosis in the connective tissue encapsulating polyethylene implants indicated the applicability of this material for test purposes. This capsule formation occurred as a result of the displacement of the connective tissue fascia and the proliferation of connective tissue elements around the implanted tubes. Yaltirik et al. (2004) reported moderate reactions of fibrous connective tissue to MTA at seven days. The reactions exhibited a decrease over time, which was statistically significant at 60 days. These findings are compatible with our study, in which no fibrous capsule formation was observed in the ProRoot White MTA and Medcem Pure Portland Cement groups on Day 30 and 60. Our findings are also partially consistent with the findings of Cintra et al. (2013) the absence of capsules at 60 days is a sign of repair by fibrosis. This indicates that ProRoot White MTA and Medcem Pure Portland Cement are well tolerated by connective tissue.

\section{Conclusion}

The results of this study suggest that Medcem MTA and Medcem Pure Portland Cement with the presence of dystrophic calcification in connective tissue have the potential to be clinic use as calcium silicate materials.

No previous studies have evaluated tissue responses to Portland cement using commercial products that meet the international medical device requirements specified by the US Food and Drug Administration. In this regard, our study makes a significant contribution to the literature. However, further in vitro as well as ex vivo studies are needed to evaluate tissue and cellular responses.

\section{Author Contributions}

All authors contributed to the study conception and design. Material preparation, data collection and analysis were performed by NT, BK, SÇ and CC. The first draft of the manuscript was written by $\mathrm{SC}$ and $S \mathrm{~B}$, all authors commented on previous versions of the manuscript. All authors read and approved the final manuscript.

\section{Conflict of Interest}

The authors declare that there is no conflict of interest.

\section{Ethical Approval/Informed Consent}

Ethical approval for this research was obtained from the Animal Experiments Ethics Committee of the University of Eskisehir Osmangazi (reference number: 46418926605.02/2020-01/12). In line with Guide for the Care and Use of Laboratory Animals (www.nap.edu/catalog/5140.html) principles, animal rights were protected.

\section{References}

Abou ElReash A, Hamama H, Abdo W, Wu Q, Zaen El-Din A, Xiaoli X. 2019. Biocompatibility of new bioactive resin composite versus calcium silicate cements: an animal study. BMC Oral Health, 19(1): 194.

Benetti F, Queiroz ÍOdA, Cosme-Silva L, Conti LC, Oliveira SHPd, Cintra LTA. 2019. Cytotoxicity, biocompatibility and biomineralization of a new ready-for-use bioceramic repair material. Brazilian Dental J, 30(4): 325-332.

Bodrumlu E. 2008. Biocompatibility of retrograde root filling materials: a review. Australian Endodontic J, 34(1): 30-35.

Bósio C, Felippe G, Bortoluzzi E, Felippe M, Felippe W, Rivero E. 2014. Subcutaneous connective tissue reactions to iR oot $\mathrm{SP}$ mineral trioxide aggregate (MTA) F illapex, D ia R oot B io A ggregate and MTA. Int Endod J, 47(7): 667-674.

Camilleri J, Pitt Ford T. 2006. Mineral trioxide aggregate: a review of the constituents and biological properties of the material. International Endodontic J, 39(10): 747-754.

Cintra LTA, Ribeiro TAA, Gomes-Filho JE, Bernabé PFE, Watanabe S, Facundo ACdS, Samuel RO, Dezan-Junior E. 2013. Biocompatibility and biomineralization assessment of a new root canal sealer and root-end filling material. Dental Traum, 29(2): 145-150.

Dawood AE, Parashos P, Wong RH, Reynolds EC, Manton DJ. 2017. Calcium silicate-based cements: composition, properties, and clinical applications. J Invest Clin Dent, 8(2): e12195.

Gomes-Filho JE, Watanabe S, Bernabé PFE, de Moraes Costa MT. 2009. A mineral trioxide aggregate sealer stimulated mineralization. J Endodontics, 35(2): 256-260.

Hinata G, Yoshiba K, Han L, Edanami N, Yoshiba N, Okiji T. 2017. Bioactivity and biomineralization ability of calcium silicatebased pulp-capping materials after subcutaneous implantation. Int Endod J, 50(Sup 2): e40-e51.

Holland R, de SOUZA V, Nery MJ, Faraco Júnior IM, Bernabé $P$, Otoboni Filho JA, Dezan Júnior E. 2001. Reaction of rat connective tissue to implanted dentin tube filled with mineral trioxide aggregate, Portland cement or calcium hydroxide. Braz Dent J, 12(1): 3-8.

Hungaro Duarte MA, de Oliveira El Kadre GD, Vivan RR, Guerreiro Tanomaru JM, Tanomaru Filho M, de Moraes IG. 2009. Radiopacity of portland cement associated with different radiopacifying agents. J Endod, 35(5): 737-740.

Islam I, Chng HK, Yap AUJ. 2006. Comparison of the physical and mechanical properties of MTA and Portland cement. J Endodontics, 32(3): 193-197.

Jefferies SR. 2014. Bioactive and biomimetic restorative materials: a comprehensive review. Part I. J Esthetic and Resto Dent, 26(1): 14-26.

Junior ES, dos Santos MGC, Oliveira LB, Mercadé M. 2019. MTA and biodentine for primary teeth pulpotomy: a systematic review and meta-analysis of clinical trials. Clinical Oral Invest, 23(4): 1967-1976.

Kaplan AE, Ormaechea M, Picca M, Canzobre M, Ubios A. 2003. Rheological properties and biocompatibility of endodontic sealers. Int Endod J, 36(8): 527-532.

Karanth P, Manjunath M, Kuriakose E. 2013. Reaction of rat subcutaneous tissue to mineral trioxide aggregate and Portland cement: a secondary level biocompatibility test. J Indian Soc of Pedodontics and Preventive Dent, 31(2): 74.

Lotfi M, Vosoughhosseini S, Saghiri MA, Mesgariabbasi M, Ranjkesh B. 2009. Effect of white mineral trioxide aggregate mixed with disodium hydrogen phosphate on inflammatory cells. J Endodontics, 35(5): 703-705.

Maeda H, Hashiguchi I, Nakamuta H, Toriya Y, Wada N, Akamine 
A. 1999. Histological study of periapical tissue healing in the rat molar after retrofilling with various materials. J Endodontics, 25(1): 38-42.

Marques NCT, Lourenço Neto N, Fernandes AP, Rodini CdO, Duarte MAH, Oliveira TM. 2013. Rat subcutaneous tissue response to MTA Fillapex® and Portland cement. Brazilian Dental J, 24(1): 10-14.

Moretton TR, Brown CE, Legan JJ, Kafrawy AH. 2000. Tissue reactions after subcutaneous and intraosseous implantation of mineral trioxide aggregate and ethoxybenzoic acid cement. J Biomed Mater Res, 52(3): 528-533.

Oliveira TMd, Moretti A, Sakai VT, Neto NL, Santos CFd, Machado MAdAM, Abdo RCC. 2013. Clinical, radiographic and histologic analysis of the effects of pulp capping materials used in pulpotomies of human primary teeth. European Archives of Paediatric Dent, 14(2): 65-71.

Olsson B, Sliwkowski A, Langeland K. 1981. Subcutaneous implantation for the biological evaluation of endodontic materials. J Endodontics, 7(8): 355-369.

Parirokh M, Torabinejad M. 2010. Mineral trioxide aggregate: a comprehensive literature review--Part III: Clinical applications, drawbacks, and mechanism of action. J Endod, 36(3): 400-413.

Parirokh M, Torabinejad M, Dummer P. 2018. Mineral trioxide aggregate and other bioactive endodontic cements: an updated overview-part I: vital pulp therapy. Int Endod J, 51(2): 177-205.

Petrou MA, Alhamoui FA, Welk A, Altarabulsi MB, Alkilzy M, Splieth HC. 2014. A randomized clinical trial on the use of medical Portland cement, MTA and calcium hydroxide in indirect pulp treatment. Clinical Oral Invest, 18(5): 13831389.

Roberts HW, Toth JM, Berzins DW, Charlton DG. 2008. Mineral trioxide aggregate material use in endodontic treatment: a review of the literature. Dental Materials, 24(2): 149-164.

Sabari MH, Kavitha M, Shobana S. 2019. Comparative Evaluation of Tissue Response of MTA and Portland Cement with Three Radiopacifying Agents: An Animal Study. J Contemp Dent Pract, 20(1): 20-25.

Saghiri MA, Lotfi M, Shokouhinejad N, Asgar K, Mehrvarzfar P. 2012. Influence of white mineral trioxide aggregate on inflammatory cells before and after expiry date. Dent
Traumatol, 28(4): 302-305.

Saidon J, He J, Zhu Q, Safavi K, Spångberg L. S. 2003. Cell and tissue reactions to mineral trioxide aggregate and Portland cement. Oral Surg, Oral Med, Oral Pathol, Oral Radiol, and Endodontology, 95(4): 483-489.

Sakai VT, Moretti ABdS, Oliveira TMd, Fornetti APC, Santos CFd, Machado MAdAM, Abdo RCC. 2009. Pulpotomy of human primary molars with MTA and Portland cement: a randomised controlled trial. British Dental J, 207(3): E5.

Sarkar N, Caicedo R, Ritwik P, Moiseyeva R, Kawashima I. 2005. Physicochemical basis of the biologic properties of mineral trioxide aggregate. J Endodontics, 31(2): 97-100.

Shayegan A, Jurysta C, Atash R, Petein M, Abbeele AV. 2012. Biodentine used as a pulp-capping agent in primary pig teeth. Pediatric Dent, 34(7): 202E-208E.

Skallevold HE, Rokaya D, Khurshid Z, Zafar MS. 2019. Bioactive Glass Applications in Dentistry. Int J Mol Sci, 20: 23.

Steffen R, Van Waes H. 2009. Understanding mineral trioxide aggregate/Portlandcement: a review of literature and background factors. European Archives of Paediatric Dent, 10(2): 93-97.

Torabinejad M, Hong CU, Lee SJ, Monsef M, Ford TRP. 1995. Investigation of mineral trioxide aggregate for root-end filling in dogs. J Endodontics, 21(12): 603-608.

Torneck CD. 1966. Reaction of rat connective tissue to polyethylene tube implants. I. Oral Surg Oral Med Oral Pathol, 21(3): 379-387.

Vilimek VM, Gateva N, Christof BS. 2018. Success rate of medcem portland cement as a pulp capping agent in pulpotomies of primary teeth. J IMAB-Annual Proceeding Sci Papers, 24(1): 1866-1871.

Yaltirik M, Ozbas H, Bilgic B, Issever H. 2004. Reactions of connective tissue to mineral trioxide aggregate and amalgam. J Endod, 30(2): 95-99.

Zhang W, Peng B. 2015. Tissue reactions after subcutaneous and intraosseous implantation of iRoot SP, MTA and AH Plus. Dent Mater J, 34(6): 774-780.

Zmener O, Lalis RM, Pameijer CH, Chaves C, Kokubu G, Grana D. 2012. Reaction of rat subcutaneous connective tissue to a mineral trioxide aggregate-based and a zinc oxide and eugenol sealer. J Endodontics, 38(9): 1233-1238. 